\title{
Pembuatan Lulur Dari Virgin Coconut Oil (VCO) Oleh Ibu PKK Desa Saba-Gianyar \\ Ngurah Indra Pradhana ${ }^{1}$
}

\begin{abstract}
ABSTRAK
Kelapa merupakan salah satu komoditas yang banyak ditemukan di Desa Saba, Kabupaten Gianyar, Propinsi Bali. Salah satunya adalah pemanfaatan kelapa menjadi Virgin Coconut Oil (VCO). Dalam pemanfaatannya, VCO dapat dikonsumsi secara langsung, untuk kosmetik, dan dipakai untuk memasak. Minyak kelapa murni ini bersifat tahan terhadap panas, cahaya, oksigen, dan tahan terhadap proses degradasi sehingga dapat disimpan hingga bertahun-tahun. Tujuan dari pelaksanaan pelatihan ini yaitu untuk mengoptimalisasi sumber daya alam yang ada di Desa Saba menjadi suatu bahan atau produk yang dapat digunakan secara massal oleh masyarakat dan meningkatan produktifitas masyarakat khususnya ibu-ibu PKK di Desa Saba sehingga dapat meningkatkan pendapatan mereka. Teknik pembuatan VCO terdiri dari pemanasan bertingkat, pengadukan, sentrifugasi, enzimatik, dan pemancingan. Teknik yang ditunjukkan adalah teknik pengadukan dengan mixer. Media kegiatan berupa alat dan bahan yang digunakan untuk menunjang kegiatan pelatihan pembuatan Virgin Coconut Oil (VCO). Media yang digunakan adalah Virgin Coconut Oil (VCO), kopi, dan tepung beras. Alat dan bahan yang digunakan berdasarkan formulasi lulur yang telah diuji dan dibuat sebelumnya. Hasil dari program ini adalah masyarakat desa Saba terutama ibu-ibu PKK dapat mengetahui bagaimana cara pembuatan minyak kelapa murni atau Virgin Coconut Oil (VCO) serta lulur dari Virgin Coconut Oil (VCO).
\end{abstract}

Kata kunci: Kelapa, VCO, Lulur

\begin{abstract}
Coconut is one of the commodities in Saba Village, Gianyar Regency, Bali Province. One of the using of coconut is Virgin Coconut Oil (VCO). In its use, VCO can be consumed directly, for cosmetics, and used for cooking. This virgin coconut oil is resistant to heat, light, oxygen, and resistant to the degradation process so that it can be stored for years. The purpose of this training is to optimize natural resources in the village of Saba into a material or product that can be used massively by the community and increase the productivity of the community especially PKK women in Saba Village so that they can increase their income. VCO making techniques consist of multilevel heating, stirring, centrifugation, enzymatic, and fishing. The technique shown is the mixing technique with a mixer. Media activities in the form of tools and materials used to support training activities in making Virgin Coconut Oil (VCO). The media used were Virgin Coconut Oil (VCO), coffee, and rice flour. Tools and materials used are based on scrub formulations that have been tested and made previously. The result of this program is that the Saba villagers, especially PKK women, can find out how to make virgin coconut oil (VCO) and scrubs from Virgin Coconut Oil (VCO).
\end{abstract}

Keywords: Coconut, VCO, scrubs

\footnotetext{
${ }^{1}$ Fakultas Ilmu Budaya, Universitas Udayana, indra_pradana@unud.ac.id
} 


\section{PENDAHULUAN}

Kelapa (Cocos nucifera) mempunyai peran yang cukup penting dalam kehidupan masyarakat Indonesia, karena kelapa banyak dibudidayakan oleh sebagian besar masyarakat sebagai tanaman tahunan yang mempunyai nilai ekonomi dan sosial. Kelapa juga sering disebut sebagai pohon kehidupan (tree of life) dan pohon surga (a heavenly tree) karena hampir semua bagian tanaman mulai dari akar, batang, daun, dan buahnya dapat dimanfaatkan untuk kehidupan. Untuk itu, kela[a bisa dikategorikan menjadi salah satu komoditas unggulan suatu daerah.

Kelapa merupakan salah satu komoditas yang banyak ditemukan di Desa Saba, Kabupaten Gianyar, Propinsi Bali. Kelapa yang ada di Desa Saba seringkali dijual ke pasar-pasar tradisional dengan harga jual yang rendah. Oleh karena itu, untuk meningkatkan harga jual, perlu diadakan pelatihan pembuatan produk dari kelapa yang dapat bermanfaat bagi masyarakat umum. Salah satunya adalah pemanfaatan kelapa menjadi Virgin Coconut Oil (VCO).

Dalam pemanfaatannya, VCO dapat dikonsumsi secara langsung, untuk kosmetik, dan dipakai untuk memasak. Minyak kelapa murni ini bersifat tahan terhadap panas, cahaya, oksigen, dan tahan terhadap proses degradasi sehingga dapat disimpan hingga bertahun-tahun. VCO merupakan minyak kelapa murni yang dalam proses pembuatannya tidak mengalami proses pemanasan atau tambahan bahan apapun sehingga komponen anti oksidannya tidak mengalami kerusakan. VCO memiliki ciri-ciri berwarna bening atau tidak berwarna, tidak berbau tengik tetapi beraroma khas kelapa. VCO memiliki banyak manfaat untuk kecantikan dan kesehatan antara lain dapat mencegah radikal bebas karena mengandung antioksidan berupa vitamin E, dapat meningkatkan metabolism tubuh, dapat meningkatkan daya tahan tubuh, mempercepat penyembuhan dan menggantikan sel-sel yang rusak dengan cepat.

\section{METODE PEMECAHAN MASALAH}

Kegiatan ini dilaksanakan di Balai Banjar Saba, Desa Saba Kec. Blahbatuh Kab. Gianyar. Virgin Coconut Oil (VCO) merupakan minyak kelapa murni yang dihasilkan dari daging kelapa segar yang diolah tanpa proses pemanasan. Tujuan dari pelaksanaan 
pelatihan ini yaitu untuk mengoptimalisasi sumber daya alam yang ada di Desa Saba menjadi suatu bahan atau produk yang dapat digunakan secara massal oleh masyarakat dan meningkatan produktifitas masyarakat khususnya ibu-ibu PKK di Desa Saba sehingga dapat meningkatkan pendapatan mereka.

Hal-hal yang dilakukan untuk melaksanakan program ini diawali dengan melakukan konsultasi dan survei berupa wawancara dan observasi terlebih dahulu kepada kepala desa, dengan mengkonsultasikan masyarakat khususnya ibu-ibu PKK yang ada diseluruh banjar yang akan diarahkan untuk mendapatkan pelatihan secara khusus, kemudian mengkoordinasikan dalam menentukan lokasi pelaksanaan kegiatan serta mempersiapkan sarana dan prasarana yang dibutuhkan untuk pelaksanaan kegiatan pelatihan yang dilaksanakan di Desa Saba.

\section{HASIL DAN PEMBAHASAN}

Kegiatan yang dilaksanakan adalah pelatihan pembuatan Virgin Coconut Oil (VCO) dan lulur dari Virgin Coconut Oil (VCO) dimulai dengan tahap persiapan dan tahap pelaksanaan. Kegiatan dimulai dengan penyampaian materi seputar VCO dan praktek pembuatan lulur dari VCO yang diikuti oleh ibu-ibu PKK Desa Saba.Teknik pembuatan VCO terdiri dari pemanasan bertingkat, pengadukan, sentrifugasi, enzimatik, dan pemancingan. Teknik yang kami tunjukkan pada ibu-ibu PKK desa Saba adalah teknik pengadukan dengan mixer. Teknik pengadukan ini bertujuan untuk memecah atau merusak protein sebagai emulgator sehingga minyak dan air dapat terpisah.

Media kegiatan berupa alat dan bahan yang digunakan untuk menunjang kegiatan pelatihan pembuatan Virgin Coconut Oil (VCO). Media yang digunakan adalah Virgin Coconut Oil (VCO), kopi, dan tepung beras. Alat dan bahan yang digunakan berdasarkan formulasi lulur yang telah diuji dan dibuat sebelumnya.

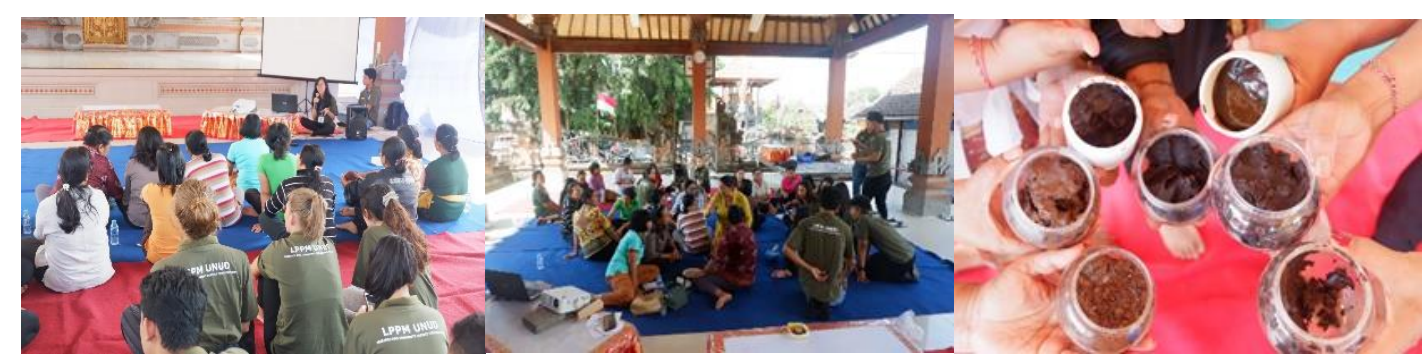

Gambar 3.1 Pelatihan pembuatan Virgin Coconut Oil (VCO) 


\section{Ngurah Indra Pradhana}

Hasil dari program bidang peningkatan produksi pelatihan ini adalah masyarakat Desa Saba terutama ibu-ibu PKK dapat mengetahui bagaimana cara pembuatan minyak kelapa murni atau Virgin Coconut Oil (VCO) serta lulur dari Virgin Coconut Oil (VCO) yang dapat dapat dijadikan suatu peluang usaha dengan memanfaatkan sumber daya alam yang ada di lingkungan sekitar.

\section{SIMPULAN}

Kegiatan yang dilaksanakan adalah pelatihan pembuatan Virgin Coconut Oil (VCO) dan lulur dari Virgin Coconut Oil (VCO) dimulai dengan tahap persiapan dan tahap pelaksanaan. Kegiatan dimulai dengan penyampaian materi seputar VCO dan praktek pembuatan lulur dari VCO yang diikuti oleh ibu-ibu PKK Desa Saba.

Hasil dari program bidang peningkatan produksi pelatihan ini adalah masyarakat Desa Saba terutama ibu-ibu PKK dapat mengetahui bagaimana cara pembuatan minyak kelapa murni atau Virgin Coconut Oil (VCO) serta lulur dari Virgin Coconut Oil (VCO) yang dapat dapat dijadikan suatu peluang usaha dengan memanfaatkan sumber daya alam yang ada di lingkungan sekitar.

\section{UCAPAN TERIMAKASIH}

Tim pelaksana mengucapkan terima kasih yang setinggi-tingginya kepada Kementerian Riset, Teknologi dan Pendidikan Tinggi, Rektor Universitas Udayana, Ketua Lembaga Penelitian dan Pengabdian Kepada Masyarakat (LP2M) Universitas Udayana melalui Program KKN-PPM XIX Tahun 2019. Terima kasih pula kami ucapkan kepada Kepala Desa, beserta aparat dan masyarakat Desa Saba, Kabupaten Gianyar, Propinsi Bali.

\section{DAFTAR PUSTAKA}

Anonim, 2017. Profil Desa Saba. Saba. Gianyar.Bali

FAO, 2010. Food and Agriculture Organization of the United Nations, Statistical databases. http://faostat.fao.org/. 